\title{
Evaluation of competition and light estimation indices for predicting diameter growth in mature boreal mixed forests
}

\author{
Kenneth J. StadT*, Carolyn Huston, K. David CoATES, Zhili Feng, Mark R.T. Dale, Victor J. LiEFFERs \\ Department of Renewable Resources, General Services Building 751, University of Alberta, Edmonton, Alberta T6G 2H1, Canada
}

(Received 23 March 2006; accepted 15 February 2007)

\begin{abstract}
A series of conventional distance-independent and distance-dependent competition indices, a highly flexible distance-dependent crowding index, and two light resource estimation indices were compared to predict individual tree diameter growth of five species of mature trees from natural-origin boreal mixed forests. The crowding index was the superior index for most species and ecosites. However, distance-independent indices, such as basal area of competing trees, were also effective. Distance-dependent light estimation indices, which estimate the fraction of seasonal photosynthetically-active radiation available to each tree, ranked intermediate to low. Determining separate competition indices for each competitor species accounted for more variation than ignoring species or classifying by ecological groups. Species' competitive ability ranked (most competitive to least): paper birch $\approx$ white spruce $\approx>$ trembling aspen $>$ lodgepole pine $>$ balsam poplar. Stratification by ecosite further improved model performance. However, the overall impact of competition on mature trees in these forests appears to be small.
\end{abstract}

competition index / photosynthetically active radiation / distance dependence / growth model / boreal mixed forest

Résumé - Évaluation de la compétition et indices d'éclairement pour la prédiction de la croissance radiale dans des forêts boréales mixtes adultes. Ce travail a évalué la capacité d'indices de compétition à prédire la croissance radiale individuelle d'arbres adultes de cinq espèces de forêts mixtes boréales. Ont ainsi été comparés : (1) une série d'indices conventionnels de compétition indépendants ou dépendants de la distance, (2) un indice très flexible d'encombrement dépendant de la distance et (3) deux indices d'estimation de l'éclairement. L'indice d'encombrement a été le plus efficace dans la plupart des stations et des espèces. Cependant, les indices indépendants de la distance tels que la surface terrière des arbres en compétition, ont été également efficaces. Les indices dépendants de la distance, d'estimation de l'éclairement, qui estiment la fraction saisonnière du rayonnement photosynthétiquement actif disponible pour chaque arbre, se sont classés en position intermédiaire. L'identification d'indices de compétition spécifiques de chaque espèce compétitrice a mieux rendu compte de la diversité des stations qu'un indice non spécifique ou qu'un classement des espèces par groupes écologiques. L'aptitude à la compétition des espèces a été classée de la manière suivante (de la plus à la moins compétitive) : Betula papyrifera, Picea glauca, Populus tremuloides, Pinus contorta, Populus balsamifera. La stratification par station améliore encore la performance du modèle. Cependant, l'impact général de la compétition sur les arbres adultes dans ces forêts semble être faible.

indice de compétition / rayonnement photosynthétiquement actif / distance dépendante / modèle de croissance / forêt boréale mixte

\section{INTRODUCTION}

Mixed species forests cover 26 million ha of the boreal plains and cordilleran regions of western Canada, comprising $75 \%$ of the forest area in Alberta, $50 \%$ of the forests of Saskatchewan, and a significant portion of southern Manitoba and northeast British Columbia [41]. The natural origin, upland forests of this region have heterogeneous mixtures of trembling aspen (Populus tremuloides), white spruce (Picea glauca (Moench.) Voss), balsam poplar (Populus balsamifera L.), lodgepole pine (Pinus contorta Dougl. ex. Loud.), and paper birch (Betula papyrifera Marsh.), which may be even- or uneven-aged $[17,38]$. Management goals for these forests focus on maintaining species and structural mixtures for biodiversity and productivity [29, 34]. As these forests are converted from natural to "semi-natural" managed sys-

*Corresponding author: ken.stadt@ualberta.ca tems [29] there is a pressing need to develop managementsensitive growth models to predict future yields. This study was undertaken to evaluate methods of modeling the complexity of intra- and inter-specific interactions in these forests.

Interactions among trees are frequently competitive, but amensalism, commensalism, and facilitation occur as well $[15,42]$. Due to the predominance of competitive interactions, indices to quantify inter-tree interactions and model tree or stand growth have been characterized as competition indices. These attempt to incorporate information about a subject tree and its neighbours, or the stand as a whole, in a way that is thought to characterize the competition levels experienced by the subject tree [9].

Distance-dependent indices are designed to capture finescale changes in competition due to the spatial arrangement of neighbours, while distance-independent indices ignore the effects of distance within the prescribed plot area. For this reason, some authors have suggested distance-dependent indices 
may be more effective for describing effects of competition on tree growth $[27,44,49]$; however, several comparative studies have found little difference between these $[2,16,19,20,22$, $33,36,51]$. It can be argued that most of these comparisons have been conducted in plantations, where there is limited variation among individual tree neighbourhoods other than the overall density [16], so distance-dependent indices may perform more effectively in more heterogeneous stands. Certainly, as stem locations are expensive and time-consuming to obtain, distance-dependent indices should demonstrate incremental benefits over distance-independent indices to justify their greater costs.

Competition indices vary in their degree of mechanistic information [40]. Recent attempts to model light levels reaching subject trees through the surrounding forest structure $[3,8,10,11,46]$ attempt to model the process of resource competition (light capture and shading), while simpler indices such as basal area or a distance-weighted size ratio [21] are less obviously related to resources. Several studies have evaluated conventional vs. resource indices for predicting juvenile tree growth reductions due to shrub, herb and tree competition $[14,37,48]$, but only one study has extended this comparison to the growth of older trees [12].

Many of the published competition indices have been developed and tested in single species stands. Studies which have applied competition indices to mixed species forests have generally treated all competing species similarly, other than allowing for different crown, stem and root allometry [22,33]. Crown and root zone size alone may not fully characterize differences among species. Shade tolerant species, for example, have much higher crown foliage density than intolerant species, resulting in more light capture by crowns of similar size $[10,11,46]$. Determining a separate competition index for each species may offer an effective method of dealing with species effects.

In the absence of competition, tree size affects the potential growth response. Younger trees develop more leaf area as they grow, increasing their photosynthetic capacity and their potential volume and stem diameter increment. However, due to the increasingly large bole perimeter, diameter increment may decline in mature individuals [18]. In inventory data where only stem diameter is measured, the effect of initial tree size may therefore be non-linear and unimodal.

Site quality is also a critical variable in forest growth modeling as it affects growth rates and may alter the competitive interactions among species. Frequently the past height growth rate of dominant trees (site index) is used to quantify site quality, but this data is often lacking in the boreal region. An alternate approach is to stratify the data by ecosites, which are designated based on climate, local topography, soil properties, and indicator species, and exhibit a relatively narrow range of SI $[4,5,24]$.

The objective of this paper is to use the large dataset of natural-origin, spatially-mapped trees in the permanent sample plot (PSP) program maintained by the Alberta Land and Forest Division [1] to compare competition indices for modeling the growth of individual trees. Specifically we wanted to test: (1) the effectiveness of conventional distance-independent and distance-dependent competition indices as well as distancedependent light resource indices as predictors of future tree diameter growth, (2) examine differences in competitive ability among the common boreal forest species, (3) compare functions for determining the effect of tree size on diameter increment, and (4) determine if competitive ability and coefficients for competition indices are different across ecosites.

\section{METHODS}

\subsection{Growth and competition data}

The Alberta Land and Forest Division Permanent Sample Plot (PSP) program is a network of more than 600 plots covering the forested areas of the province [1]. The earliest plots were established in 1960, and additional plots have been added up to the present. The original purpose of these plots was to determine the optimal rotation age for this forest, consequently plots were placed in stands nearing merchantable size, which were typically older than 60 years. Remeasurement intervals varied from 3-11 years. PSP areas are from 200 to $2000 \mathrm{~m}^{2}$. For this study, only plots equal to or larger than $400 \mathrm{~m}^{2}$ were used to allow an adequate buffer for calculating distance-dependent competition indices.

PSPs have been established in many ecosites; however, as numbers are low in some, we chose plots from the four most frequent and commercially important mixedwood ecosites: boreal mixedwood (BM) $\mathrm{d}$ and e, and lower foothills (LF) e and f. The BM ecoregion is characterized by typical maximum summer temperatures of $20.2{ }^{\circ} \mathrm{C}$, mean annual temperatures of $1.5^{\circ} \mathrm{C}$ and $389 \mathrm{~mm}$ of precipitation. The $\mathrm{LF}$ ecoregion is at higher elevation, has cooler summers $\left(18.3^{\circ} \mathrm{C}\right.$ typical maximum) and $75 \mathrm{~mm}$ more precipitation than the $\mathrm{BM}$ area. The BMd and LFe ecosites are characterized by the presence of Viburnum edule and have a mesic moisture class and medium nutrient class. BMe and LFf ecosites are subhygric and rich. The former is characterized by Cornus stolonifera and the latter by Lonicera involucrata $[4,5]$.

Individual tree data included the tree species, a disease and damage assessment, stem diameter at breast height $(d b h ; 1.3 \mathrm{~m})$, and stem location as distance and bearing from plot centre. Only the trees with $d b h$ greater or equal to $9.1 \mathrm{~cm}$ were consistently identified and mapped. The top height and live crown length of one to three trees in most of the PSPs were also measured.

In this study, the five most abundant tree species in the PSPs, trembling aspen, balsam poplar, paper birch, lodgepole pine, and white spruce, were selected for analysis. Lodgepole pine rarely occurs in the $\mathrm{BM}$ ecosites, and paper birch did not occur in BMe PSPs, so analysis of these species was confined to ecosites where they are common. Jack pine (Pinus banksiana) is abundant in the boreal mixedwood region, but uncommon in the PSP dataset, since few plots were located in northeast region of the province. PSPs with a significant presence (defined as $\geqslant 5 \%$ of the total plot basal area at breast height, BA) of species other than the common species noted above, were excluded from the analysis. Where other species occurred at low abundance $(<5 \%$ BA) they were assigned to the most ecologically similar competitor species, i.e. black spruce and balsam fir were treated as white spruce in all ecosites, as were lodgepole pine and jack pine in BM ecosites. Growth increment data from these less common species was not used in the analysis. Dead trees were ignored completely. 
Annual diameter growth increments were calculated for undamaged subject trees, which occurred near the centre of the plot, a minimum of $8 \mathrm{~m}$ from the plot edge and within a $20 \times 20 \mathrm{~m}$ square area surrounding plot centre. Annual growth was calculated as the change in diameter between remeasurements divided by the remeasurement interval. Since the numerous plots and trees provided ample spatial replication, only the first remeasurement interval was used in this analysis, avoiding temporal dependencies in the data.

\subsection{Competition indices}

A series of distance-independent, distance-dependent competition and light estimation indices (Tab. I) were calculated for each subject tree. Distance-independent indices were calculated based on trees in the central $20 \times 20 \mathrm{~m}$ section of each PSP. To attempt to capture the asymmetric nature of competition for light in a distanceindependent index, the sum of competitor basal area indices was also determined using only the trees with greater height than the subject tree $(\mathrm{CBA}>\mathrm{H}$; Tab. I). Height was estimated from stem diameter using the provincial height vs. diameter equations [23]. Most distancedependent indices were calculated using an $8 \mathrm{~m}$ search radius of each subject tree. This was a practical radius given the size of the plots and approximately conforms to Lorimer's [33] recommendation of a plot radius approximately 3.5 times the radius of the crowns of the coniferous trees. We also tested an angle gauge selector to include trees if the elevation angle from the mid-crown position on the subject tree to the top of the competitor tree was greater than $45^{\circ}$. Gauges that include trees based on the horizontal angle to the competitor trees' diameter have been more commonly tested in the literature, but for mixtures of species with different stem-crown allometry and competitive ability, the elevation angle gauge makes more sense in terms of competition for light [51]. The $45^{\circ}$ angle limit was chosen since this approximates the average elevation angle of the brightest region of the sky over the growing season (determined using techniques outlined in previous work $[43,46]$. We used the $45^{\circ}$ gauge for two indices: the sum of horizontal angles (HAS45) and the sum of sine of elevation angles (SEAS45) (Tab. I). We developed the SEAS45 index as an elevation angle analog to Lin's [32] horizontal angle sum.

To determine the impacts of neighbours of different species within each ecosite, conventional competition indices were calculated separately for each species of competitor. These competitor species indices were then used with subject tree diameter (see below) in a multiple regression model to predict future growth of the subject tree (Eq. (4)). To introduce ecosite, we fit lengthy linear models using Equation (4) plus additional indicator variables for ecosite and ecosite interactions with initial $d b h$ and each competitor species' index. These models (one for each competition index listed in Tab. I) were then compared in terms of the model's $R^{2}$ and RMSE. We also tested for similarity among the competitive ability of ecological groupings of species by calculating selected competition indices at a group level rather than a species level. Groups tested were hardwood (aspen, poplar, birch) and softwood (spruce, pine), shade tolerant (birch, spruce) and shade-intolerant (aspen, poplar). A model was also tested that combined all species into a single competition index (e.g. total competitor basal area vs. species-specific basal area). The test was for a reduction in the residual sum-of-squares comparing group-level to species-level competition indices [39]. For groups of species, Equation 4 was used, with the competition index calculated and a corresponding coefficient estimated for the group (e.g. $\beta_{\text {Hardwood }} C I_{\text {Hardwood }}$.
The crowding index [12] is a more flexible extension of traditional distance-dependent competition models, and has been incorporated into the spatially-explicit SORTIE-BC forest dynamics model [13]. The crowding effect of a neighbouring tree on the diameter growth of a subject tree of a given species is assumed to vary as a power function of the size of the neighbour, and as an inverse power function of the distance to the neighbour. The net effect of an individual neighbour is multiplied by a species-specific modifier $\left(\lambda_{i}\right)$ that ranges from 0 to 1 and allows for differences among species in their competitive effect on the subject tree. The analysis also estimates the neighbourhood area as a fraction of the maximum neighbourhood radius $(8 \mathrm{~m})$. The best performing formulation of this crowding index from Canham et al. [12] was tested here (CRWD , Tab. I, Eq. (5)).

The light resource indices were estimates of the average growing season (May to September) transmission of photosyntheticallyactive radiation as a percentage of above-canopy radiation at the center of each subject tree crown (with the subject crown removed). This was estimated using two PAR penetration algorithms [12,46]. Both algorithms summarize the radiation sources (sunlight, skylight) into a hemispherical radiance distribution then use this distribution to weight the penetration of beams into the tree canopy. In the simpler PAR penetration model, $($ PARO $=$ PAR model with Opaque crowns, [12]), tree crowns are represented as rectangular billboards orthogonal to a line drawn from the crown center of the subject tree to the neighbour, and with the height, crown length and width of the tree. The crowns are assumed to be opaque, as previous work indicated that intercrown gaps account for much of the light penetration in northern coniferous forests $[11,26]$. PAR transmission is estimated as the radiance-weighted proportion of 21600 rays which do not intercept a crown, each ray representing areas of equal solid angle across the upper hemisphere above 30 degrees elevation.

The more complex PAR penetration model (PART = PAR model with Transmissive crowns, [46]) uses a similar radiance-weighted, beam penetration technique to calculate PAR transmission, but includes both inter- and intra-crown gaps. It represents individual tree crowns as geometric shapes (cylinders, cones, ellipsoids, paraboloids or combinations) and places leaf area randomly within each geometric crown. Rays that intersect crowns have their PAR transmission reduced by the probability of finding a gap over the distance the beam travels through the crown, given the leaf area density and leaf inclination distribution specified for crowns of that species. Interspecific differences are accounted for in this model, both in terms of crown size - stem diameter relationships and within-crown leaf area density and inclination. 480 rays are traced across the full upper hemisphere, and their transmission values are radiance-weighted to give the average seasonal PAR transmission value.

The two PAR indices required several variables that were not included in the original PSP data set. Tree height was calculated from the provincial height vs. stem diameter functions [23]. Crown length and crown width were also estimated from diameter, using functions developed in this region [47]. Species-specific crown shapes, leaf area density and leaf inclination values for the PART index were taken from [46].

\subsection{Subject tree size effects}

Ideally, the effect of subject tree size on potential diameter growth is assessed by monitoring competition-free phytometer trees [9]. In our natural origin boreal stands, this information is not available and must be estimated from the available data. We assumed that potential 
Table I. Conventional competition and light resource indices tested in this study.

\begin{tabular}{lll}
\hline Index & $\begin{array}{l}\text { Abbreviation } \\
\text { (units) }\end{array}$ & Formula $^{\mathrm{e}}$ \\
&
\end{tabular}

No competition (Eqs. (1), (3))

Basal area ${ }^{\mathrm{a}}$ - all competitors

$$
\text { - taller competitors }
$$

Sum of ratios of competitor to subject dbh [33] ${ }^{\mathrm{a}}$

Sum of ratios of competitor to subject tree basal area [16 $]^{\mathrm{a}}$

Sum of overtopping competitor crown areas [7] ${ }^{\mathrm{a}}$

Hegyi [21] ${ }^{b}$

Martin-Ek [36]

Alemdag [2] ${ }^{\mathrm{b}}$

Horizontal angle sum ${ }^{\mathrm{c}}$

$(\operatorname{Lin}[32])^{\mathrm{c}}$

Sine of elevation angle sum

SEAS45

(radians)

Crowding [12] ${ }^{\mathrm{d}}$

Seasonal PAR, opaque crowns [12]

Seasonal PAR, transmissive

crowns [46]

NOCI

$\mathrm{CBA}_{\mathrm{i}}$

$\mathrm{CBA}>\mathrm{H}_{\mathrm{i}}$

$\left(\mathrm{m}^{2} / \mathrm{ha}\right)$

$\mathrm{C} / \mathrm{SDBH}_{\mathrm{i}}$

$\left(/ \mathrm{m}^{2}\right)$

$\mathrm{C}_{\text {SBA }}$

$\left(/ \mathrm{m}^{2}\right)$

CRCOV

(unitless)

HEYG $_{i}$

(/m)

MAEK $_{i}$

HAS45

(radians)

PARO

PART
ALEM8 $_{i}$

$\frac{1}{A} \frac{\pi}{4} \sum_{j=1}^{n_{i}} d b h_{i j}^{2}$

$\frac{1}{A} \frac{1}{d b h_{s t}} \sum_{j=1}^{n_{i}} d b h_{i j}$

$\frac{1}{A} \frac{1}{d b h_{s t}^{2}} \sum_{j=1}^{n_{i}} d b h_{i j}^{2}$

$\frac{\pi}{A} \sum_{j=1}^{n_{i}} c r_{i j}^{2}$

$\frac{1}{d b h_{s t}} \sum_{j=1}^{n_{i}} \frac{d b h_{i j}}{\left(d_{i j}+1\right)}$

$\frac{1}{d b h_{s t}} \sum_{j=1}^{n_{i}}\left(d b h_{i j} \exp \left[-\frac{16 \times d_{i j}}{d b h_{i j}+d b h_{s t}}\right]\right)$

$\pi \sum_{j=1}^{n_{i}}\left(\left[\frac{d b h_{s t} \times d_{i j}}{d b h_{s t}+d b h_{i j}}\right]^{2}\left[\frac{d b h_{i j} / d_{i j}}{\sum_{t=1}^{n_{s}}\left\{d b h_{i j} / d_{i j}\right\}}\right]\right)$

$2 \sum_{j=1}^{n_{i}} \tan ^{-1}\left(\frac{1}{2} \frac{d b h_{i j}}{d_{i j}}\right)$

$\sum_{j=1}^{n_{i}} \sin \left[\tan ^{-1}\left(\frac{h_{i j}-\left(h_{s t}-\frac{1}{2} c l_{s t}\right)}{d_{i j}}\right)\right]$

$\sum_{i=1}^{n_{s}} \lambda_{i} \sum_{j=1}^{n_{i}} \frac{d b h_{i j}^{\alpha}}{d_{i j}^{\beta}}$

See Materials and methods

${ }^{a}$ Distance-independent indices calculated based on trees selected in the central $20 \times 20 \mathrm{~m}$ region of the plot but are scaled to be independent of plot area.

${ }^{\mathrm{b}}$ Distance-dependent indices based on an $8 \mathrm{~m}$ search radius.

${ }^{c}$ Distance-dependent indices based on a $>45$ elevation angle selection.

${ }^{\mathrm{d}}$ Distance-dependent index based on a search radius $\leqslant 8 \mathrm{~m}$ (see Methods).

${ }^{\mathrm{e}} d b h(\mathrm{~cm})$ is stem diameter at $1.3 \mathrm{~m}$ height, $n_{s}$ is the number of competitor species, $n_{i}$ is the number of trees of competitor species $i$ in the plot, $j$ is the competitor tree number, $s$ is the subject tree species, $t$ is the subject tree number, $A\left(\mathrm{~m}^{2}\right)$ is the plot area, and $c r_{i j}$ is the crown radius (m) of the competitor, $d_{i j}(\mathrm{~m})$ is the distance from the competitor tree to the subject tree, $h(\mathrm{~m})$ is tree height, and $c l(\mathrm{~m})$ is crown length. The subject tree was not included as a competitor in any index. 
diameter growth would vary with the diameter of the target tree. We tested two growth vs. diameter functions: a simple linear function (Eq. (1)) and a log-normal function (Eq. (2)). These represent two strategies to model the balance of leaf area and maintenance demands as well as allocation changes as a tree increases in size [12].

$$
\begin{gathered}
P O T G_{s t}=\beta_{0, s}+\beta_{d b h, s} d b h_{s t} \\
P_{O T G_{s t}}=M A X G_{s} \exp \left\{-\frac{1}{2}\left[\frac{\ln \left(d b h_{s t} / m_{s}\right)}{b_{s}}\right]^{2}\right\}
\end{gathered}
$$

Here $P O T G_{s t}$ is the annual breast-height diameter growth of a tree $t$ of species $s$ without competition, $d b h_{s t}$ is the current diameter of the same tree, $M A X G_{s}$ is the maximum diameter growth achieved by the species at a diameter of $m_{s}$, and $b_{s}$ is the standard deviation (breadth) of the species' log-diameter response. These parameters were estimated simultaneously with coefficients for the competition indices.

\subsection{Growth models}

Diameter growth of a subject tree was modeled first by testing the current diameter effect alone without competitor effects (NOCI, Eq. (3)), then by adding the competition effect of the various species (Eq. (4)). The reduction in the sum of squares from Equations (3) to (4) measures the effect of including competition.

$$
G_{s t}=P O T G_{s t}+\varepsilon_{s t}
$$

$$
\begin{aligned}
G_{s t}= & P O T G_{\text {st }}+\beta_{\text {Aspen }} C I_{\text {Aspen }}+ \\
& \beta_{\text {Poplar }} C I_{\text {Poplar }}+\beta_{\text {Birch }} C I_{\text {Birch }}+\beta_{\text {Pine }} C I_{\text {Pine }}+\beta_{\text {Spruce }} C I_{\text {Spruce }}+\varepsilon_{\text {st }}
\end{aligned}
$$

Here, $G_{s t}$ is the annual diameter growth of subject tree $t$ of species $s$, $P O T G_{s t}$ is the annual stem diameter growth of a tree of this size and species without competition (Eq. (1) or (2)), $\beta_{\text {Aspen }}, \beta_{\text {Poplar }}, \beta_{\text {Birch }}$, $\beta_{\text {Pine }}$, and $\beta_{\text {Spruce }}$ are the coefficients for the competition indices for each competitor species $\left(C I_{\text {Aspen }}, C I_{\text {Poplar }}, C I_{\text {Birch }}, C I_{\text {Pine }}\right.$, and $C I_{\text {Spruce }}$; see Tab. I for formulae for each index), and $\varepsilon_{s t}$ is the error, which was assumed to be independent and normally distributed for these and all subsequent models. A multiplicative model of initial size and species' competitive effects was also assessed; however, like Canham et al. [12], we found the additive model (Eq. (4)) much superior. A multiplicative model may perform well for juvenile and mid-rotation growth, but for mature stands, size and competition appear to have additive effects.

For the neighbourhood crowding index, the competitor species effects are estimated by both the magnitude of the crowding coefficient, $c$, and the individual species' coefficients, $\lambda_{i}$. The software written to estimate these coefficients [12] did not include the ability to estimate a linear current diameter effect, so only the log-normal function was tested for this index. The growth model is given by Equation (5),

$$
\begin{aligned}
G_{s t}=M A X G_{s} \exp \left\{-1 / 2\left[\ln \left(d b h_{s t} / m_{s}\right) / b_{s}\right]^{2}\right\} \\
+c\left\{\Sigma_{i}\left[\lambda_{i} \Sigma_{j}\left(d b h_{i j}^{\alpha} / d_{i j}^{\beta}\right)\right]\right\}+\varepsilon_{s t}
\end{aligned}
$$

\begin{tabular}{|c|c|c|c|c|c|c|c|}
\hline \multirow{3}{*}{$\begin{array}{l}\text { Ecosite } \\
\text { (\# of plots) }\end{array}$} & \multirow[t]{3}{*}{ Species } & \multicolumn{6}{|c|}{ Plots } \\
\hline & & \multicolumn{3}{|c|}{ Density (stems/ha) } & \multicolumn{3}{|c|}{ Basal area $\left(\mathrm{m}^{2} / \mathrm{ha}\right)$} \\
\hline & & Mean & Min & Max & Mean & Min & Max \\
\hline $\mathrm{BMd}$ & All & 1066 & 20 & 2173 & 25.3 & 0.6 & 49.6 \\
\hline \multirow[t]{4}{*}{ (109) } & Aspen & 582 & 5 & 1930 & 12.4 & 0.2 & 37.7 \\
\hline & Birch & 110 & 5 & 1481 & 1.7 & 0.1 & 15.0 \\
\hline & Poplar & 129 & 5 & 690 & 3.3 & 0.1 & 23.2 \\
\hline & Spruce & 559 & 5 & 2148 & 15.2 & 0.2 & 36.3 \\
\hline $\mathrm{BMe}$ & All & 795 & 30 & 1630 & 28.9 & 0.2 & 50.3 \\
\hline \multirow[t]{4}{*}{ (13) } & Aspen & 275 & 30 & 1160 & 7.0 & 0.2 & 13.1 \\
\hline & Birch & 43 & 5 & 70 & 1.0 & 0.2 & 2.0 \\
\hline & Poplar & 204 & 10 & 460 & 7.9 & 1.0 & 19.2 \\
\hline & Spruce & 671 & 320 & 1290 & 28.4 & 18.1 & 41.1 \\
\hline $\mathrm{LFe}$ & All & 884 & 110 & 2467 & 29.0 & 3.2 & 51.1 \\
\hline \multirow[t]{5}{*}{ (82) } & Aspen & 338 & 5 & 1498 & 11.0 & 0.2 & 33.9 \\
\hline & Birch & 71 & 10 & 247 & 1.7 & 0.1 & 7.0 \\
\hline & Poplar & 127 & 5 & 425 & 4.1 & 0.0 & 17.4 \\
\hline & Pine & 528 & 10 & 2437 & 15.9 & 0.2 & 35.6 \\
\hline & Spruce & 356 & 5 & 1235 & 12.9 & 0.0 & 51.1 \\
\hline LFf & All & 903 & 89 & 2519 & 28.7 & 10.2 & 44.7 \\
\hline \multirow[t]{5}{*}{ (95) } & Aspen & 108 & 5 & 1540 & 5.4 & 0.1 & 20.4 \\
\hline & Birch & 49 & 5 & 198 & 1.2 & 0.1 & 5.9 \\
\hline & Poplar & 97 & 5 & 360 & 3.9 & 0.2 & 9.7 \\
\hline & Pine & 785 & 5 & 2173 & 22.8 & 0.5 & 35.8 \\
\hline & Spruce & 218 & 2 & 1187 & 8.3 & 0.1 & 40.2 \\
\hline
\end{tabular}

where $d b h_{i j}$ is the breast-height diameter $(\mathrm{cm})$ of the $j t h$ competing tree of species $i$, and $\mathrm{d}_{i j}$ is the distance (m) from the subject tree to this competitor. The exponents $\alpha$ and $\beta$ are coefficients that modify the shape of the diameter and distance response.
Table II. Plot density and basal area by ecosite and species for the Alberta Land and Forest Division mixedwood permanent sample plots.

The seasonal PAR resource indices account for the species composition surrounding the subject tree by determining light penetration between and through the crowns of the different species. Since species effects are thus accounted for already, the growth model using the PARO or PART indices (PAR_) is given by Equation (6). To convert the PAR indices from light availability to shading (i.e. competition), we used their complement (i.e. shading $=100-P A R_{-}$).

$$
G_{s t}=P O T G_{s t}+\beta_{P A R} \times\left(100-P A R_{-}\right)+\varepsilon_{s t}
$$

To allow for separate indices of above and below ground competition, we also tested combinations of light resource and conventional indices. The first assumed competitor basal area captured the belowground competition [27] if the transmissive tree PAR index simultaneously captured above-ground competition $(C B A+P A R T$, Eq. (7)).

$$
\begin{gathered}
G_{\text {st }}=P O T G_{\text {st }}+\beta_{\text {Aspen }} C B A_{\text {Aspen }}+\beta_{\text {Poplar }} C B A_{\text {Poplar }}+\beta_{\text {Birch }} C B A_{\text {Birch }}+ \\
\beta_{\text {Pine }} C B A_{\text {Pine }}+\beta_{\text {Spruce }} C B A_{\text {Spruce }}+\beta_{\text {PAR }}(100-P A R T)+\varepsilon_{s t}
\end{gathered}
$$

where $C B A$ is the basal area per hectare of the competitors of the subscript species and the other indexes and coefficients are as defined above.

The second combination tested crowding as the below-ground index of competition and opaque tree PAR as the above-ground index (CRWD+PARO, Eq. (8)).

$$
\begin{aligned}
G_{s t}=M A X G_{s} \exp \left\{-1 / 2\left[\ln \left(d b h_{s t} / m_{s}\right) / b_{s}\right]^{2}\right\} & +c\left\{\Sigma_{i}\left[\lambda_{i} \Sigma_{j}\left(d b h_{i j}^{\alpha} / d_{i j}^{\beta}\right)\right]\right\} \\
& +\beta_{P A R}(100-\% P A R O)+\varepsilon_{s t} .
\end{aligned}
$$


Table III. Mean and range of stem diameter $(d b h)$ and annual diameter increment of subject trees in each species and ecosites.

\begin{tabular}{|c|c|c|c|c|c|c|c|c|}
\hline \multirow[t]{2}{*}{ Ecosite } & \multirow[t]{2}{*}{ Species } & \multirow[t]{2}{*}{ \# of trees } & \multicolumn{3}{|c|}{$d b h(\mathrm{~cm})$} & \multicolumn{3}{|c|}{ Annual $d b h$ growth $(\mathrm{cm} / \mathrm{y})$} \\
\hline & & & Mean & Min & $\operatorname{Max}$ & Mean & Min & Max \\
\hline \multirow[t]{4}{*}{ BMd } & Aspen & 1160 & 15.7 & 9.1 & 48.8 & 0.038 & -0.178 & 0.728 \\
\hline & Birch & 130 & 14.5 & 9.1 & 31.2 & 0.038 & -0.092 & 0.340 \\
\hline & Poplar & 216 & 17.6 & 9.1 & 53.4 & 0.048 & -0.040 & 0.714 \\
\hline & Spruce & 668 & 18.3 & 9.1 & 66.0 & 0.032 & -0.120 & 0.728 \\
\hline \multirow[t]{3}{*}{$\mathrm{BMe}$} & Aspen & 99 & 17.0 & 9.1 & 46.8 & 0.064 & 0.000 & 0.640 \\
\hline & Poplar & 96 & 22.1 & 9.2 & 48.8 & 0.070 & -0.080 & 0.614 \\
\hline & Spruce & 127 & 22.1 & 9.1 & 67.1 & 0.032 & -0.066 & 0.640 \\
\hline \multirow[t]{5}{*}{$\mathrm{LFe}$} & Aspen & 646 & 19.7 & 9.1 & 51.3 & 0.048 & -0.100 & 0.684 \\
\hline & Birch & 71 & 17.5 & 9.4 & 29.5 & 0.054 & -0.050 & 0.328 \\
\hline & Poplar & 235 & 19.1 & 9.1 & 39.1 & 0.066 & 0.000 & 0.716 \\
\hline & Pine & 579 & 19.5 & 9.1 & 47.2 & 0.034 & -0.072 & 0.684 \\
\hline & Spruce & 447 & 21.2 & 9.1 & 56.6 & 0.054 & -0.066 & 0.766 \\
\hline \multirow[t]{5}{*}{ LFf } & Aspen & 283 & 25.0 & 9.1 & 55.6 & 0.088 & -0.072 & 0.716 \\
\hline & Birch & 83 & 16.9 & 9.1 & 31.2 & 0.034 & -0.100 & 0.328 \\
\hline & Poplar & 235 & 20.9 & 9.1 & 58.9 & 0.124 & 0.000 & 0.766 \\
\hline & Pine & 2065 & 19.9 & 9.1 & 54.1 & 0.050 & -0.134 & 0.766 \\
\hline & Spruce & 457 & 21.7 & 9.1 & 60.2 & 0.058 & -0.162 & 0.794 \\
\hline
\end{tabular}

\subsection{Model fitting, comparison and reduction}

Ordinary least-squares regression was used to fit growth models with conventional empirical indices and linear current diameter functions (PROC REG, SAS v.9.1, SAS Institute Inc. 2004). The full model, including all competitor species, ecosite and interaction effects, was used to compare competition indices. Best subsets regression was used to determine the best fitting (highest $R^{2}$ ) combination of competitor species' CBA indices that had significance levels greater than 0.05. An iterative least-squares procedure using a secant approximation (PROC NLIN METHOD=DUD, SAS v.9.1, SAS Institute Inc. 2004) was used to fit the conventional and PART indices using the log-normal current diameter function. We used the diameter of the largest tree of each species - ecosite combination to set the initial value for the diameter $\left(m_{s}\right.$, Eq. (2)) at maximum growth. Since the crowding index has coefficients nested within the summation (Eq. (5), Tab. I), more complex techniques were required to estimate these parameters. We used maximum likelihood with simulated annealing to fit this model (see [12] for details).

For the commonly used competitor basal area index (CBA), we tested for differences due to distinguishing ecosites, competitor species, and competitor hardwood/softwood and shade tolerant/intolerant groups with a test for differences in residual sumsof-squares between the more detailed "full" $\left(S S_{\text {res,full }}\right)$ and reduced models ( $\left.S S_{\text {res,reduced }}\right)$ [39]. For distinguishing ecosites, we compared the $S S_{\text {res }}$ values from fitting Equation (4) separately to each ecosite $\left(S S_{r e s, f u l l}=S S_{r e s, B M d}+S S_{r e s, B M e}+S S_{r e s, L F e}+S S_{r e s, L F f}\right)$ to the $S S_{r e s}$ from fitting Equation (4) once to all ecosites together $\left(S S_{\text {res,reduced }}\right)$. For distinguishing among competitor species, we computed residual sums of squares using Equation (4) vs. a modification of this equation with only one competition index term (and only one $\beta$ ) calculated across all species $\left(S S_{\text {res,reduced }}\right)$. We also compared distinguishing among all species $\left(S S_{\text {res,full }}\right.$, Eq. (4)) with only considering hardwood/softwood or shade tolerant/intolerant groups by modify- ing Equation (4) to determine competition indices for these groups $\left(S S_{\text {res,reduced }}\right)$. The $F$ statistic for these comparisons is given by Equation (9) with ( $\left.d f_{\text {res,reduced }} d f_{\text {res,full }}\right)$ and $d f_{\text {res,full }}$ degrees of freedom.

$$
F=\frac{S S_{\text {res,reduced }}-S S_{\text {res,full }}}{d f_{\text {res, }, \text { reduced }}-d f_{\text {res, full }}} \mid \frac{S S_{\text {res,full }}}{d f_{\text {res }, \text { full }}} .
$$

\section{RESULTS}

The plot density and basal area for the five subject species (aspen, balsam poplar, lodgepole pine, paper birch and white spruce) are summarized by species and ecosite in Table II. Each species showed a wide range of variation in density and basal area within each ecosite, although birch and poplar were generally less abundant components of the plots. In the BMe plots, which are wetter and richer [4], aspen was also less abundant. White spruce had the largest range of initial diameter as well as the highest diameter growth rates (Tab. III) in the data set, followed closely by poplar, aspen and pine, while birch were smaller trees with less than half the diameter growth of other species (Tab. III). Negative growth values were seen frequently in suppressed trees. This is a common problem in a harsh climate where measurement error is frequently larger than the growth of suppressed trees, even over long remeasurement intervals.

A linear model of initial subject tree diameter alone without competition effects (Eqs. (1) and (3), NOCI in Fig. 1) accounted for 11 to $31 \%$ of the total variation (i.e. the coefficient of determination, $R^{2}$ ) in diameter growth across ecosites. When fit separately by ecosite, this model was not significant $(P>0.05)$ in three cases: aspen in the BMd ecosite, birch in the BMd ecosite, and poplar in the LFf ecosite. For 
pine, the log-normal function of diameter (Eqs. (2) and (3)) was marginally better (larger coefficient of determination) than the linear function, but for all other species across the four ecosites, values of the coefficient of determination $\left(R^{2}\right)$ were similar (data not shown). Further, the diameter at maximum growth parameter $\left(m_{s}\right)$ converged on values near or greater than the maximum diameter for each species in the data, so that these log-normal functions describe an increase in diameter growth with current diameter up to the maximum values, similar to the linear diameter function.

However, since the trees in these data were subject to varying degrees of competition, the subject-tree diameter effect is better evaluated when coupled with a competition index (Eqs. (4) and (5)). In this case, the effects of diameter were similar. Linear functions of diameter were significant for most species and ecosites (Tab. IV). Here too, the log-normal diameter function converged on typically high values of diameter $\left(m_{s}\right.$, Tab. IV) at maximum growth. $R^{2}$ values were virtually identical for both the linear and log-normal diameter functions and inspection of residuals demonstrated no obvious patterns to favour one function over the other. The linear function of diameter is more parsimonious ( 2 vs. 3 parameters), though both functions yielded similar trends for the range of diameter in this data.

All diameter growth models were significant with residual standard errors of 0.06-0.15, and coefficients of determination $\left(R^{2}\right)$ varying from 0.08 to 0.55 (Fig. 1, Tabs. IV and V). These models accounted for significantly more of the total variation than a model based on subject-tree diameter (NOCI) alone $(P<0.05)$.

To check for collinearity among the predictors, we examined the condition number [39] for each linear model before any model reduction was performed (Tab. IV). The birch growth model for the BMe ecosite had a condition number $(=40)$ that was greater than the critical value of 30 [39], indicating a moderate degree of collinearity. Further investigation indicated that the presence of birch in this ecosite was weakly associated with aspen, so some caution would be prudent in using the parameters of this model. No significant collinearity was found for the predictors in other species and ecosites.

Figure 1 shows the coefficient of determination $\left(R^{2}\right)$ of each competition index model including ecosite and ecosite interactions in order to assess the effectiveness of the numerous competition indices across ecosites by each subject tree species. Among the single competition index models, the distance-dependent crowding index (CRWD) was superior for all species except aspen. The distance-dependent Martin-Ek index (MAEK8) and sum of the sine of the elevation angles (from subject tree midcrown to competitors' apices; SEAS45) were second and third in rank, followed closely by several distance-independent indices, basal area of competitors (CBA), Biging and Dobbertin's [7] overtopping crown cover (CRCOV), and basal area of taller competitors $(\mathrm{CBA}>\mathrm{H})$. The competitor/subject tree size ratio indices (HEYG8, C/SBA, C/SDBH) were intermediate and there was no consistent improvement in fit in Heygi's [21] distance-dependent diameter ratio index over a similar but distance independent index (C/SDBH, [33]). Alemdag's [2]
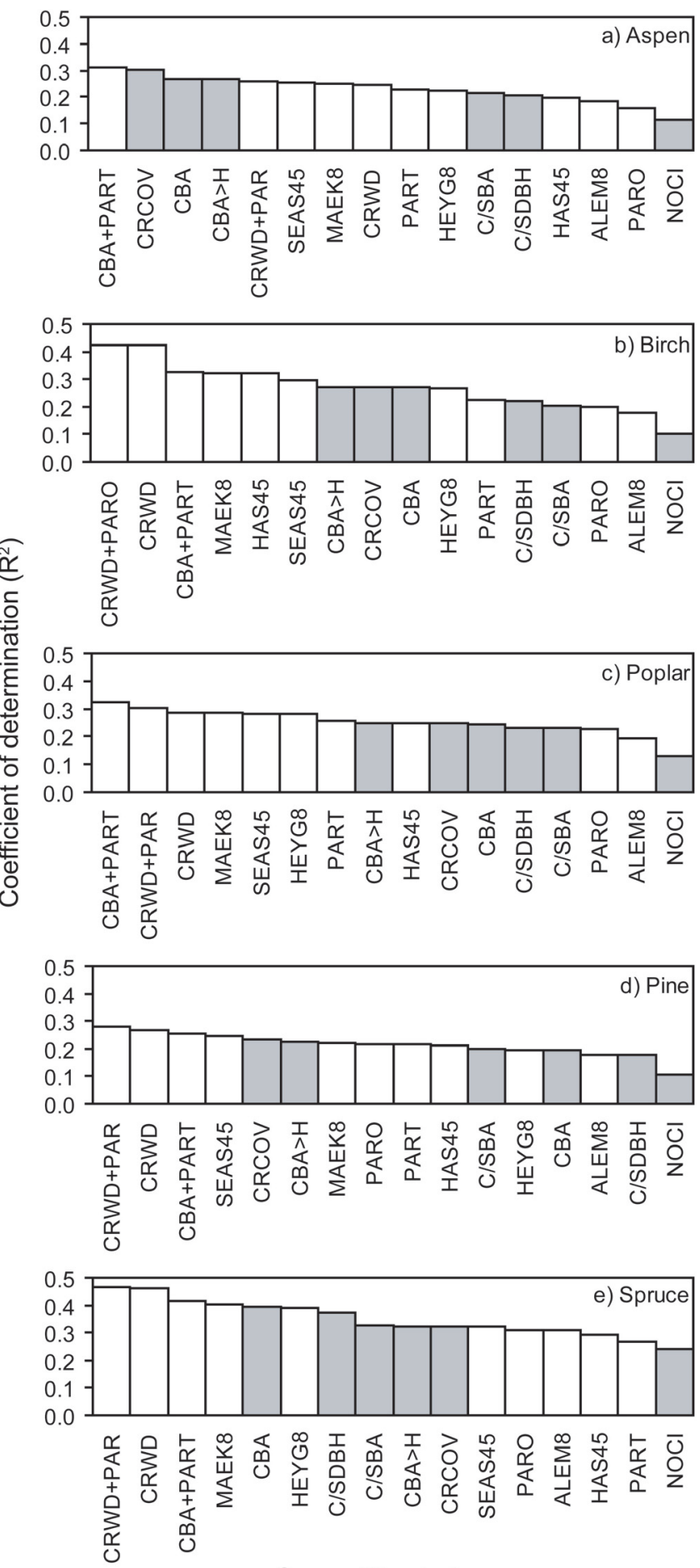

Competition index

Figure 1. Coefficients of determination $\left(R^{2}\right)$ for models with current subject-tree diameter response functions only (Eqs. (1-3), NOCI) and models with both current diameter response functions and competition indices (Eqs. (4-8), abbreviations and formulae for competition indices are listed in Tab. I). To evaluate which are the more effective competition indices overall, results shown here are for models common to all ecosites. Distance-dependent models are shown in white, distance-independent in gray. The response variable is the annual diameter growth of each of the five subject species. 
Table IV. Regression coefficients and statistics for a model using a linear function of subject tree diameter $(\mathrm{dbh}$, $\mathrm{cm})$ and the basal area of the competitors of each species as the competition index (Eq. (4)). The response variable is annual diameter growth at breast height (cm/y).

\begin{tabular}{|c|c|c|c|c|c|c|c|c|c|c|c|}
\hline \multirow[t]{2}{*}{ Ecosite } & \multirow[t]{2}{*}{ Species } & \multirow[t]{2}{*}{$R^{2}$} & \multirow{2}{*}{$\begin{array}{c}\text { Residual } \\
\text { standard } \\
\text { error }\end{array}$} & \multicolumn{2}{|c|}{$\begin{array}{l}\text { Coefficients for a linear } \\
\text { growth response to subject tree } d b h\end{array}$} & \multicolumn{5}{|c|}{$\begin{array}{l}\text { Coefficients for competitor basal } \\
\text { area as a competition index }\end{array}$} & \multirow[t]{2}{*}{$\begin{array}{c}\text { Condition number } \\
\text { (before model reduction }^{\mathrm{b}} \text { ) }\end{array}$} \\
\hline & & & & Intercept $\left(\beta_{0}\right)$ & $\beta_{d b h}$ & $\beta_{\text {Aspen }}$ & $\beta_{\text {Birch }}$ & $\beta_{\text {Poplar }}$ & $\beta_{\text {Pine }}$ & $\beta_{\text {Spruce }}$ & \\
\hline \multirow[t]{4}{*}{ BMd } & Aspen & 0.16 & 0.109 & +0.188 & +0.00539 & -0.00342 & $*$ & $*$ & & -0.00586 & 8.37 \\
\hline & Birch & 0.32 & 0.071 & +0.291 & $*$ & -0.00795 & -0.00862 & $*$ & & -0.00876 & 24.62 \\
\hline & Poplar & 0.30 & 0.111 & +0.162 & +0.00587 & -0.00587 & $*$ & $*$ & & -0.00576 & 11.31 \\
\hline & Spruce & 0.34 & 0.099 & +0.220 & +0.00515 & $*$ & $*$ & $*$ & & -0.00635 & 12.92 \\
\hline \multirow[t]{3}{*}{$\mathrm{BMe}$} & Aspen & 0.26 & 0.116 & +0.359 & $*$ & -0.00770 & & -0.00549 & & -0.00659 & 10.10 \\
\hline & Poplar & 0.11 & 0.121 & +0.250 & $*$ & $*$ & & $*$ & & -0.00471 & 10.48 \\
\hline & Spruce & 0.35 & 0.095 & +0.089 & +0.00617 & $*$ & & $*$ & & -0.00261 & 13.18 \\
\hline \multirow[t]{5}{*}{$\mathrm{LFe}$} & Aspen & 0.36 & 0.093 & +0.145 & +0.00807 & -0.00439 & $*$ & $*$ & -0.00476 & -0.00651 & 11.30 \\
\hline & Birch & 0.27 & 0.062 & -0.009 & +0.00878 & $*$ & -0.00338 & $*$ & $*$ & $*$ & 40.88 \\
\hline & Poplar & 0.08 & 0.116 & +0.142 & +0.00544 & $*$ & $*$ & $*$ & -0.00262 & $*$ & 10.72 \\
\hline & Pine & 0.23 & 0.088 & +0.034 & +0.00797 & -0.00373 & $*$ & -0.00359 & $*$ & -0.00944 & 14.70 \\
\hline & Spruce & 0.51 & 0.109 & +0.279 & +0.00688 & -0.00769 & -0.00414 & $*$ & -0.00348 & -0.00738 & 11.86 \\
\hline \multirow[t]{5}{*}{ LFf } & Aspen & 0.25 & 0.129 & +0.143 & +0.00699 & -0.00537 & $*$ & +0.00374 & $*$ & -0.00627 & 12.93 \\
\hline & Birch & 0.27 & 0.072 & -0.062 & +0.00876 & $*$ & $*$ & $*$ & $*$ & $*$ & 14.06 \\
\hline & Poplar & 0.17 & 0.145 & +0.366 & $*$ & -0.00574 & -0.01264 & $*$ & $*$ & -0.00783 & 11.53 \\
\hline & Pine & 0.19 & 0.090 & +0.082 & +0.00796 & -0.00480 & -0.01180 & -0.00711 & -0.00222 & -0.00570 & 15.84 \\
\hline & Spruce & 0.32 & 0.118 & +0.191 & +0.00623 & -0.00635 & $*$ & -0.00863 & -0.00288 & -0.00411 & 13.57 \\
\hline
\end{tabular}

${ }^{a}$ An asterisk $(*)$ indicates this regressor was removed by best subsets regression. Where cells are blank, the subject species did not occur in sufficient numbers to estimate a coefficient.

${ }^{\mathrm{b}}$ Condition number with all competitor species included in the model.

Table V. Regression coefficients and statistics for a model using a log-normal function of subject tree diameter $(d b h$, $\mathrm{cm})$ and the neighbourhood crowding index (Eq. (5)). The response variable is annual diameter growth at breast height (cm/y).

\begin{tabular}{|c|c|c|c|c|c|c|c|c|c|c|c|c|c|c|c|}
\hline \multirow[t]{2}{*}{ Ecosite } & \multirow[t]{2}{*}{$\begin{array}{c}\text { Subject } \\
\text { tree species }\end{array}$} & \multirow[t]{2}{*}{$R^{2}$} & \multirow[t]{2}{*}{$\begin{array}{l}\text { Residual } \\
\text { standard } \\
\text { error }\end{array}$} & \multicolumn{3}{|c|}{$\begin{array}{c}\text { Coefficients for a } \\
\text { lognormal growth response } \\
\text { to subject tree } d b h\end{array}$} & \multicolumn{8}{|c|}{$\begin{array}{l}\text { Coefficients for } \\
\text { the crowding index }\end{array}$} & \multirow[t]{2}{*}{$\begin{array}{c}\text { Search } \\
\text { radius, } \mathrm{R}(\mathrm{m})\end{array}$} \\
\hline & & & & $M A X G$ & $m_{s}$ & $b$ & $c$ & $\lambda_{\text {Aspen }}$ & $\lambda_{\text {Birch }}$ & $\lambda_{\text {Poplar }}$ & $\lambda_{\text {Pine }}$ & $\lambda_{\text {Spruce }}$ & $\alpha$ & $\beta$ & \\
\hline \multirow[t]{4}{*}{ BMd } & Aspen & 0.22 & 0.106 & 0.449 & 106.5 & 2.02 & -0.782 & 0.312 & 0.034 & 0.249 & 0.065 & 0.690 & 2.316 & 0.161 & 5.7 \\
\hline & Birch & 0.42 & 0.068 & 0.208 & 98.6 & 3.00 & -0.038 & 0.167 & 0.001 & 0.042 & 0.726 & 0.918 & 0.134 & 0.308 & 5.3 \\
\hline & Poplar & 0.34 & 0.110 & 0.369 & 55.0 & 1.32 & -0.351 & 0.401 & 0.727 & 0.191 & 0.001 & 0.745 & 1.612 & 0.692 & 5.8 \\
\hline & Spruce & 0.41 & 0.095 & 0.410 & 100.9 & 2.89 & -0.258 & 0.012 & 0.101 & 0.158 & 0.900 & 0.743 & 1.560 & 0.649 & 7.6 \\
\hline \multirow[t]{3}{*}{$\mathrm{BMe}$} & Aspen & 0.40 & 0.111 & 0.455 & 29.6 & 1.14 & -0.773 & 0.851 & 0.040 & 0.256 & 0.151 & 0.695 & 2.891 & 0.013 & 7.5 \\
\hline & Poplar & 0.48 & 0.100 & 0.480 & 82.0 & 2.01 & -0.956 & 0.367 & 0.791 & 0.520 & 0.621 & 0.795 & 2.181 & 0.728 & 6.8 \\
\hline & Spruce & 0.55 & 0.082 & 0.351 & 113.4 & 1.55 & -0.013 & 0.021 & 0.097 & 0.119 & 0.921 & 0.957 & 0.067 & 0.365 & 3.4 \\
\hline \multirow[t]{5}{*}{$\mathrm{LFe}$} & Aspen & 0.28 & 0.099 & 0.392 & 64.0 & 1.31 & -0.228 & 0.396 & 0.143 & 0.016 & 0.476 & 0.879 & 2.525 & 0.001 & 8.0 \\
\hline & Birch & 0.40 & 0.061 & 0.450 & 139.1 & 1.48 & -0.550 & 0.254 & 0.969 & 0.262 & 0.033 & 0.273 & 2.810 & 0.050 & 6.1 \\
\hline & Poplar & 0.16 & 0.114 & 0.335 & 54.1 & 1.93 & -0.047 & 0.629 & 0.031 & 0.159 & 0.431 & 0.466 & 0.753 & 0.541 & 8.0 \\
\hline & Pine & 0.29 & 0.085 & 0.282 & 30.0 & 0.78 & -0.640 & 0.344 & 0.891 & 0.394 & 0.126 & 0.695 & 1.963 & 0.582 & 7.3 \\
\hline & Spruce & 0.54 & 0.106 & 0.592 & 188.1 & 2.63 & -0.075 & 0.982 & 0.542 & 0.037 & 0.453 & 0.749 & 1.450 & 0.002 & 7.7 \\
\hline \multirow[t]{5}{*}{ LFf } & Aspen & 0.21 & 0.135 & 0.508 & 170.1 & 1.80 & -0.951 & 0.111 & 0.924 & 0.014 & 0.002 & 0.914 & 3.206 & 0.090 & 5.5 \\
\hline & Birch & 0.44 & 0.068 & 0.235 & 40.5 & 1.09 & -0.379 & 0.458 & 0.497 & 0.033 & 0.098 & 0.600 & 2.421 & 0.011 & 7.8 \\
\hline & Poplar & 0.27 & 0.139 & 0.462 & 50.7 & 3.89 & -0.087 & 0.921 & 0.741 & 0.466 & 0.705 & 0.548 & 0.806 & 0.435 & 7.3 \\
\hline & Pine & 0.26 & 0.086 & 0.437 & 86.7 & 1.48 & -0.964 & 0.582 & 0.952 & 0.620 & 0.668 & 0.916 & 3.259 & 0.281 & 7.9 \\
\hline & Spruce & 0.41 & 0.110 & 0.445 & 44.2 & 1.38 & -0.411 & 0.700 & 0.049 & 0.237 & 0.567 & 0.621 & 2.435 & 0.158 & 7.5 \\
\hline
\end{tabular}


Table VI. Effect of distinguishing among competitor species and competitor groups when calculating competing basal area. Table values are $F$ statistics ( $d f_{\text {numerator }}, d f_{\text {denominator }}$, and $P$ value) for the change in residual sums-of-squares (Eq. (9)).

\begin{tabular}{|c|c|c|c|c|}
\hline \multirow[t]{2}{*}{ Subject species } & \multirow[t]{2}{*}{ Ecosite } & \multicolumn{3}{|c|}{ Comparison } \\
\hline & & $\begin{array}{l}\text { Combine competitor species } \\
\text { vs. distinguish all } \\
\text { competitor species }\end{array}$ & $\begin{array}{c}\text { Distinguish } \\
\text { hardwood/softwood } \\
\text { competitor groups vs. } \\
\text { distinguish all competitor species }\end{array}$ & $\begin{array}{l}\text { Distinguish shade } \\
\text { tolerant/intolerant competitor } \\
\text { groups vs. distinguish all } \\
\text { competitor species }\end{array}$ \\
\hline \multirow[t]{4}{*}{ Aspen } & BMd & $10.42(4,1153, P<0.0001)$ & $2.29(3,1153, P=0.0773)$ & $2.05(3,1153, P=0.1058)$ \\
\hline & $\mathrm{BMe}$ & $1.09(3,93, P=0.3568)$ & $0.48(2,93, P=0.6217)$ & $0.39(2,93, P=0.6775)$ \\
\hline & $\mathrm{LFe}$ & $13.24(4,639, P<0.0001)$ & $9.90(3,639, P<0.0001)$ & $8.83(3,639, P<0.0001)$ \\
\hline & LFf & $11.68(4,276, P<0.0001)$ & $14.84(3,276, P<0.0001)$ & $6.64(3,276, P=0.0002)$ \\
\hline \multirow[t]{3}{*}{ Birch } & BMd & $5.33(4,123, P=0.0005)$ & $4.48(3,123, P=0.0051)$ & $4.73(3,123, P=0.0037)$ \\
\hline & $\mathrm{LFe}$ & $3.30(4,64, P=0.0160)$ & $0.35(3,64, P=0.7858)$ & $2.53(3,64, P=0.0648)$ \\
\hline & LFf & $1.62(4,76, P=0.1773)$ & $2.15(3,76, P=0.1011)$ & $1.12(3,76, P=0.3465)$ \\
\hline \multirow[t]{4}{*}{ Poplar } & BMd & $3.53(4,209, P=0.0082)$ & $3.88(3,209, P=0.0099)$ & $3.80(3,209, P=0.0110)$ \\
\hline & $\mathrm{BMe}$ & $0.67(3,90, P=0.5749)$ & $0.60(2,90, P=0.5496)$ & $0.60(2,90, P=0.5510)$ \\
\hline & $\mathrm{LFe}$ & $1.98(4,228, P=0.0982)$ & $1.21(3,228, P=0.3061)$ & $2.61(3,228, P=0.0524)$ \\
\hline & LFf & $4.21(4,228, P=0.0026)$ & $5.60(3,228, P=0.0010)$ & $2.98(3,228, P=0.0322)$ \\
\hline \multirow[t]{2}{*}{ Pine } & $\mathrm{LFe}$ & $31.36(4,572, P<0.0001)$ & $37.66(3,572, P<0.0001)$ & $11.70(3,572, P<0.0001)$ \\
\hline & LFf & $21.24(4,2058, P<0.0001)$ & $15.67(3,2058, P<0.0001)$ & $7.40(3,2058, P<0.0001)$ \\
\hline \multirow[t]{4}{*}{ Spruce } & BMd & $28.98(4,662, P<0.0001)$ & $5.07(3,662, P=0.0018)$ & $8.06(3,662, P<0.0001)$ \\
\hline & $\mathrm{BMe}$ & $3.53(3,123, P=0.0169)$ & $1.87(2,123, P=0.1587)$ & $1.78(2,123, P=0.1724)$ \\
\hline & $\mathrm{LFe}$ & $13.22(4,465, P<0.0001)$ & $16.08(3,465, P<0.0001)$ & $12.22(3,465, P<0.0001)$ \\
\hline & LFf & $5.82(4,498, P=0.0001)$ & $2.78(3,498, P=0.0406)$ & $7.30(3,498, P<0.0001)$ \\
\hline
\end{tabular}

distance-dependent index (ALEM8) behaved poorly. The two light resource indices (PARO, PART) were intermediate to poor compared to the conventional indices. The transmissive crown light index (PART) performed better than the opaque crown light index for aspen and poplar but these indices performed similarly for birch, pine and spruce.

The difference between the best single distance-dependent and distance-independent indices was variable depending on the subject species. Birch showed the largest improvement in distance-dependent over distance-independent indices (improvement in $\left.R^{2}=0.13\right)$, with poplar second (0.08), and then white spruce (0.07), and pine (0.04), while for aspen the difference was small (0.01) (Fig. 1). Full statistics, coefficients and residual plats for one of the better distance-independent (basal area of competitors) and the best distance-dependent (CRWD) index are provided in Tables IV and V and Figures 3 and 4.

The combination of basal area and transmissive-crown PAR indices (CBA+PART, Eq. (7) and the combination of crowing and opaque-crown PAR indices (CRWD+PARO, Eq. (8)) was generally a small improvement over the crowding index alone (CRWD) (Fig. 1).

Separate models for each ecosite explained significantly more residual variation than a common model which ignored ecosites $(P<0.0001$ for all five subject species; Tab. VI). This was also shown by some variation in the effect of competitor species' basal area on subject species' growth from ecosite to ecosite (Fig. 2). Separate growth equations for each ecosite were therefore used for testing the effects of distinguishing among competitor species.

Differences among species in reducing the growth of subject trees were also demonstrated by reductions in the residual sum-of-squares compared to models which did not distinguish species in determining competitor basal area. This was true for all but four of 17 subject species and ecosite combinations (Tab. VI). Models with all competitor species distinguished were better than a model with only hardwood-softwood competitor groups or a model with shade tolerant-intolerant groups in ten out 17 subject species-ecosite combinations (Tab. VI).

The competitive ability of a species is indicated by how much it reduces the growth of other (subject) trees. In the absence of significant collinearity with the indices for other species, this is indicated by the size of the regression coefficient for the species' competition index. Figure 2 compares the coefficients of the basal area index. Birch had an intermittent but strong negative effect on tree growth, whereas white spruce, followed by aspen, were consistently moderate competitors. Lodgepole pine was a light to moderate competitor in some ecosites. Balsam poplar was occasionally a moderate competitor; however, in the LFf ecosite, it was also associated with a positive effect on aspen growth. 


\section{DISCUSSION}

The crowding index, the most flexible distance-dependent index tested in these highly structured mixed-species forests, offered some improvement over distance-independent indices for predicting the diameter growth of boreal trees. It performed similar to the competitor basal area index for predicting aspen growth, but had consistently higher $R^{2}$ and lower residual standard errors for the other species. The flexible shape of the competitor diameter and distance response in the crowding index facilitated this better performance, but required optimization techniques to estimate the coefficients. The next-best indices were the distance-dependent size-ratio index developed by Martin and Ek (MAEK8, [36]) and the sum of the sine of elevation angles to competitors (SEAS45). The simpler structure of these indices permitted coefficient estimation by leastsquares regression. The fits of these indices were marginally better than distance-independent indices, e.g. the sum of competitor basal areas (CBA), or the overtopping crown cover index (CRCOV).

Other comparisons of distance-independent vs. dependent models have shown mixed results, with some studies finding better performance of distance-dependent over distance-independent models $[2,6,19]$ while others found marginal to no improvement $[16,20,33,36,49,51]$. Biging and Dobbertin [7] found that distance-independent indices using various measures of the amount of overtopping crowns were equivalent or superior to distance-dependent indices. Likewise, we found that their overtopping crown cover index (CRCOV, Fig. 1) was similar in fit to most other distancedependent indices, except the crowding index. More recent work has focused on distance-dependent indices that have yielded respectable performance for single-species growth in plantations [27,44], or mixed-species natural forests [12,50], but these studies did not test distance-independent indices. Our results indicate that there may be some improvement from using distance information in a highly flexible index, but that the improvement in fit over distance-independent indices needs to be evaluated carefully relative to the cost of obtaining treelevel coordinates.

The light resource indices (PART, PARO) ranked intermediate to low in their ability to predict diameter growth. This may indicate that resources other than light are also limiting. The effectiveness of the competitor basal area index, and, for spruce, its better fit compared to competitor basal area in taller trees suggests that some type of below-ground resource such as nutrients or water may be more important for at least some species in these mature stands. Certainly, the simultaneous fit of a light resource index (to represent above-ground competition) with another index (basal area, crowding) to represent below-ground competition improved the predictive ability of the growth model. Larocque [27] tested a similar approach for plantation red pine, where the volume overlap of crowns of adjacent trees was used to estimate above-ground competition, and basal area to estimate root competition. Larocque measured crown dimensions directly, which may account for the respectable fit of his growth models $\left(R^{2} \geqslant 0.70\right)$. Direct crown measurements have not been made in our mixedwood

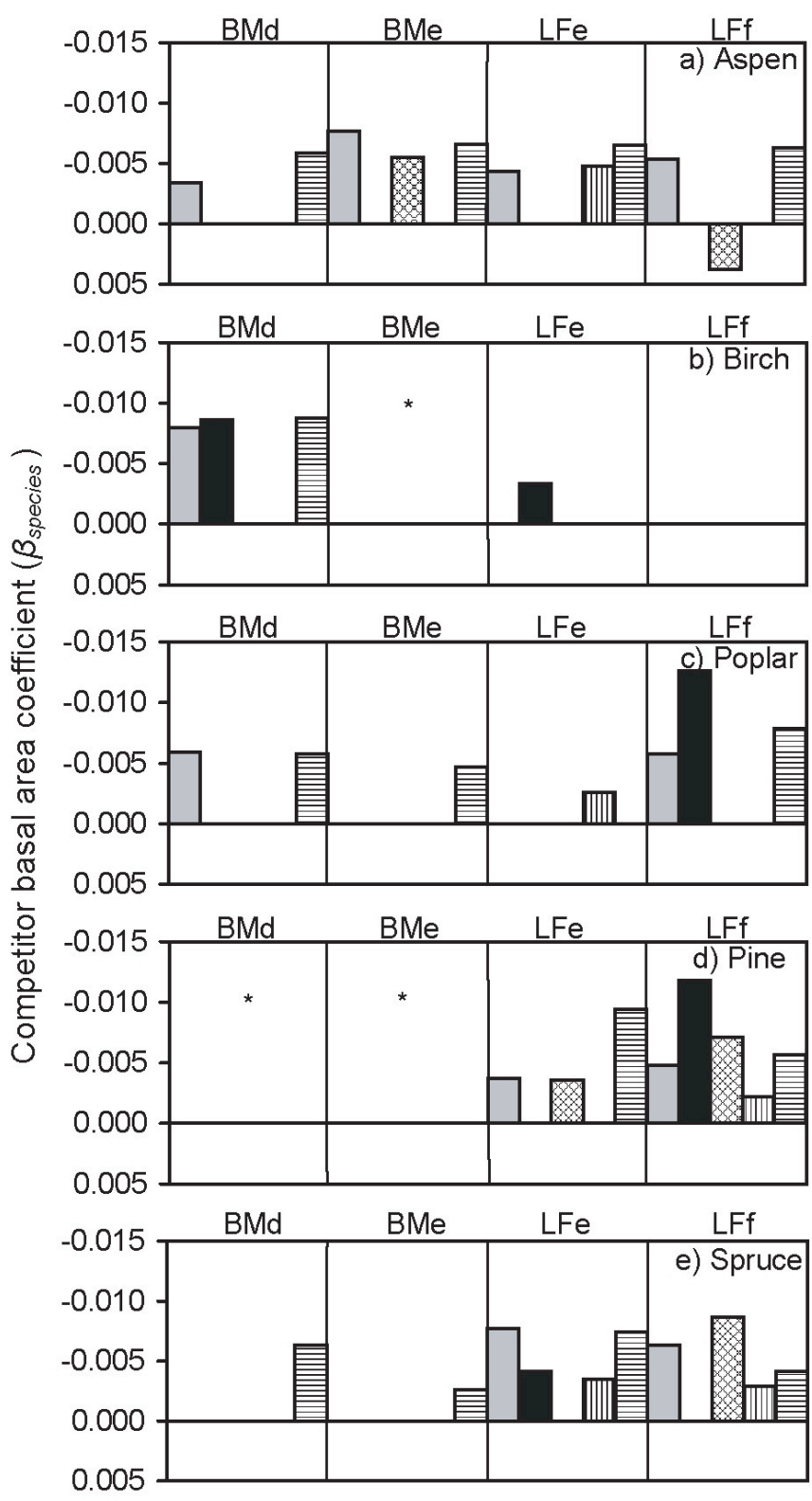

Competitor: $\square$ Aspen $\square$ Birch $⿴$ Poplar $\square$ Pine 目Spruce

Figure 2. Comparison of the competitive effect of each subject tree species on annual diameter growth $(\mathrm{cm} / \mathrm{y})$ by ecosites. This effect is estimated by coefficients $\left(\beta_{\text {species }}\right.$, Eq. (4)) for the competition index using the basal area $\left(C B A, \mathrm{~m}^{2} / \mathrm{ha}\right)$ of each competing species for each ecosite. Note that the direction of the $y$-axis is reversed. An asterix $(*)$ indicates that the subject species has low numbers in this ecosite. Where bars have a zero value, this species' basal area effect was not significant $(P>0.05)$ in this ecosite.

forests as a routine part of the forest inventory. Our reliance on simple allometric relationships between stem diameter and crown dimensions with limited precision [47] may be part of the reason for the poorer fit of our resource-based indices. This additional information required by light resource and other crown-dimension based indices $[6,7,27]$ is also costly to obtain in a forest inventory. The similarity amongst the fit of 

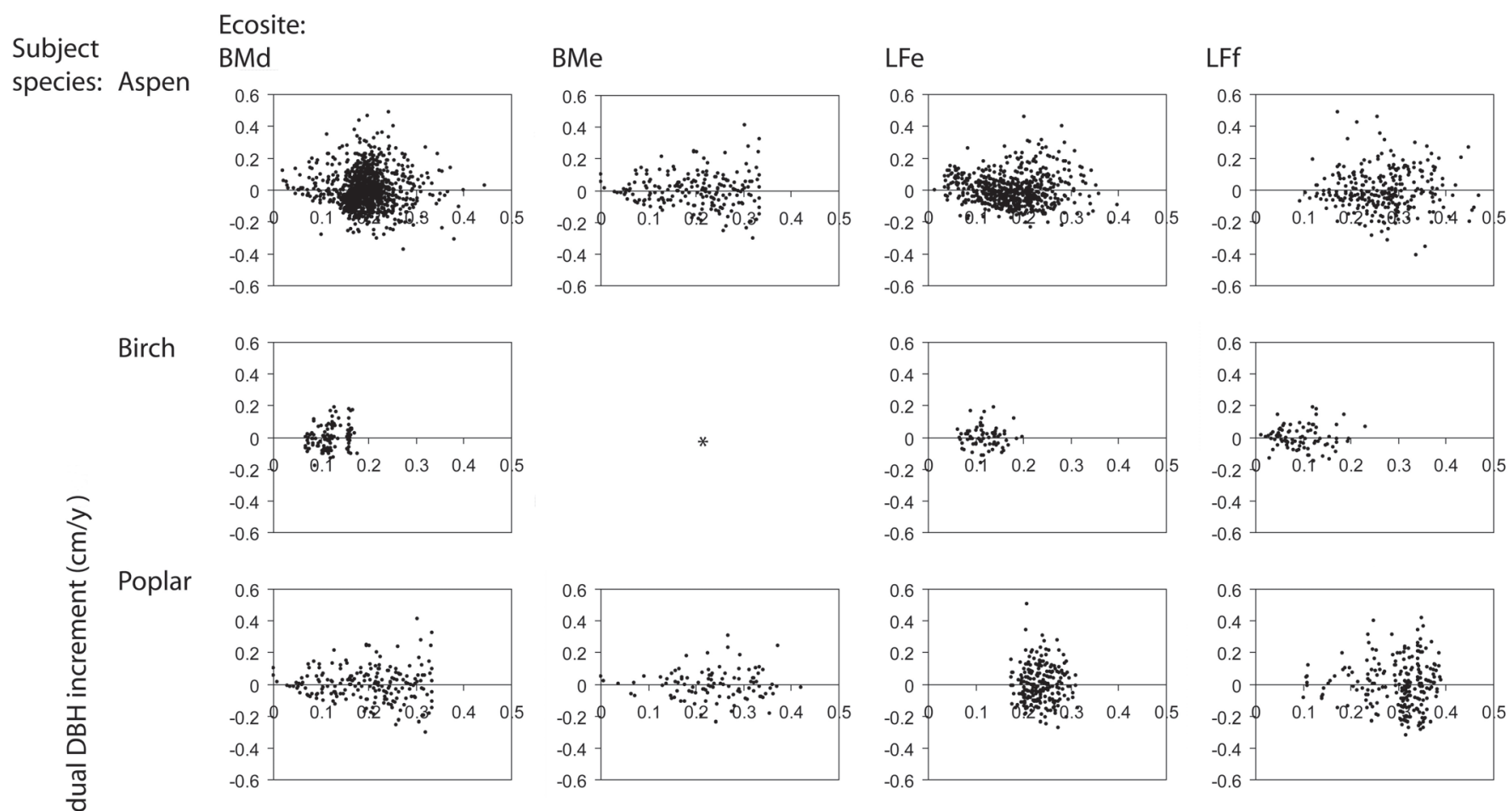

Pine
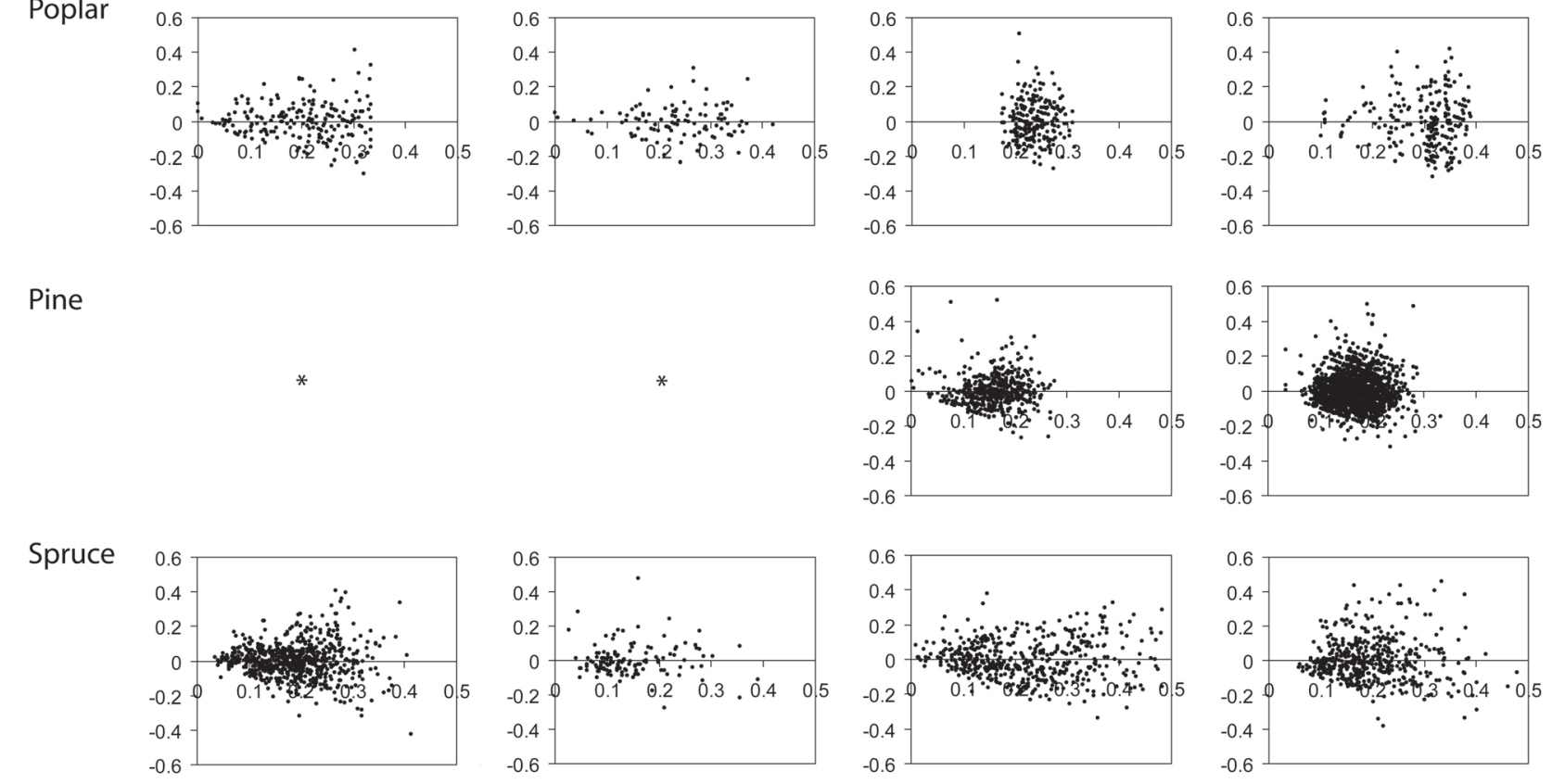

Predicted DBH increment $(\mathrm{cm} / \mathrm{y})$

Figure 3. Residual plots for annual $d b h$ growth (observed - predicted vs. predicted) for the competitor basal area model (Eqs. (1) and (4)) by ecosite and subject tree species. Missing plots (*) are due to insufficient numbers of some species in some ecosites.

these competition indices may be partially due to the need to derive many of the quantities needed to calculate the indices (e.g. crown dimensions) from the simpler data collected in the PSP sampling (e.g. $d b h)$.

Modeling the growth of mixed species forests presents an additional challenge compared to monocultures, since species differ in their effect on resource levels as well as their response to them. Previous work has focused on modeling light (PAR) availability using species' crown size and leaf area submodels, then linking PAR received to tree growth [3, 10, 11,47]. Our attempt to do this yielded only intermediate results, as noted above. We found better results when PAR indices were combined with other competition indices such as competitor basal area or crowding, intended in this instance to reflect below-ground interactions. However, as our current PSP data are limited to treelists of species, dbh, and stem coordinates, the PAR indices as applied here were really non-linear transformations of tree dbh. For this reason again, simpler speciesstructured and dbh-based models such as competitor basal area or crowding as indices of competition were nearly as effective as combined PAR-conventional index models.

Species effects in these simpler models must be dealt with by computing separate indices for each species and estimating their effect by multiple regression or optimization. The 

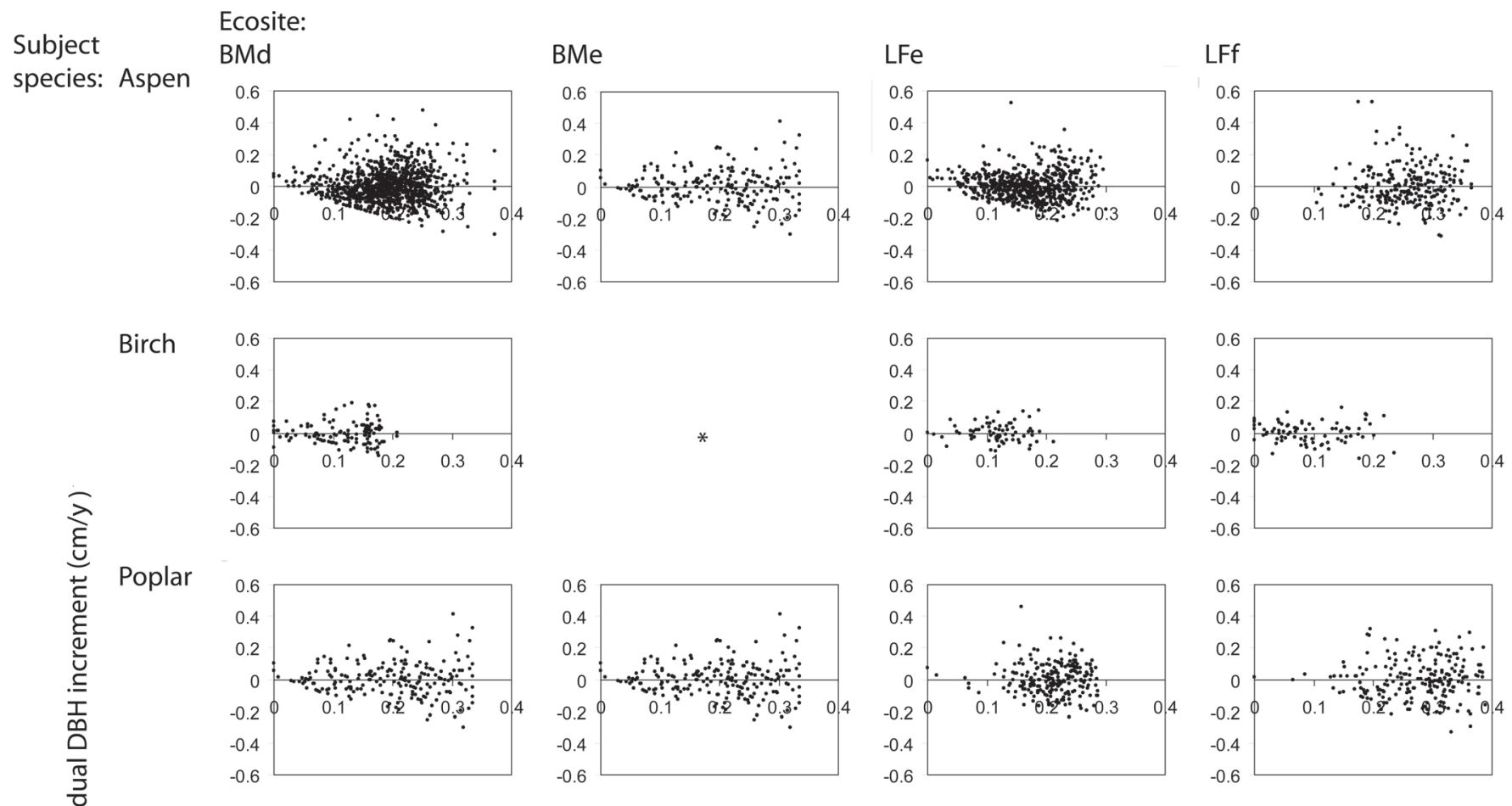

Pine
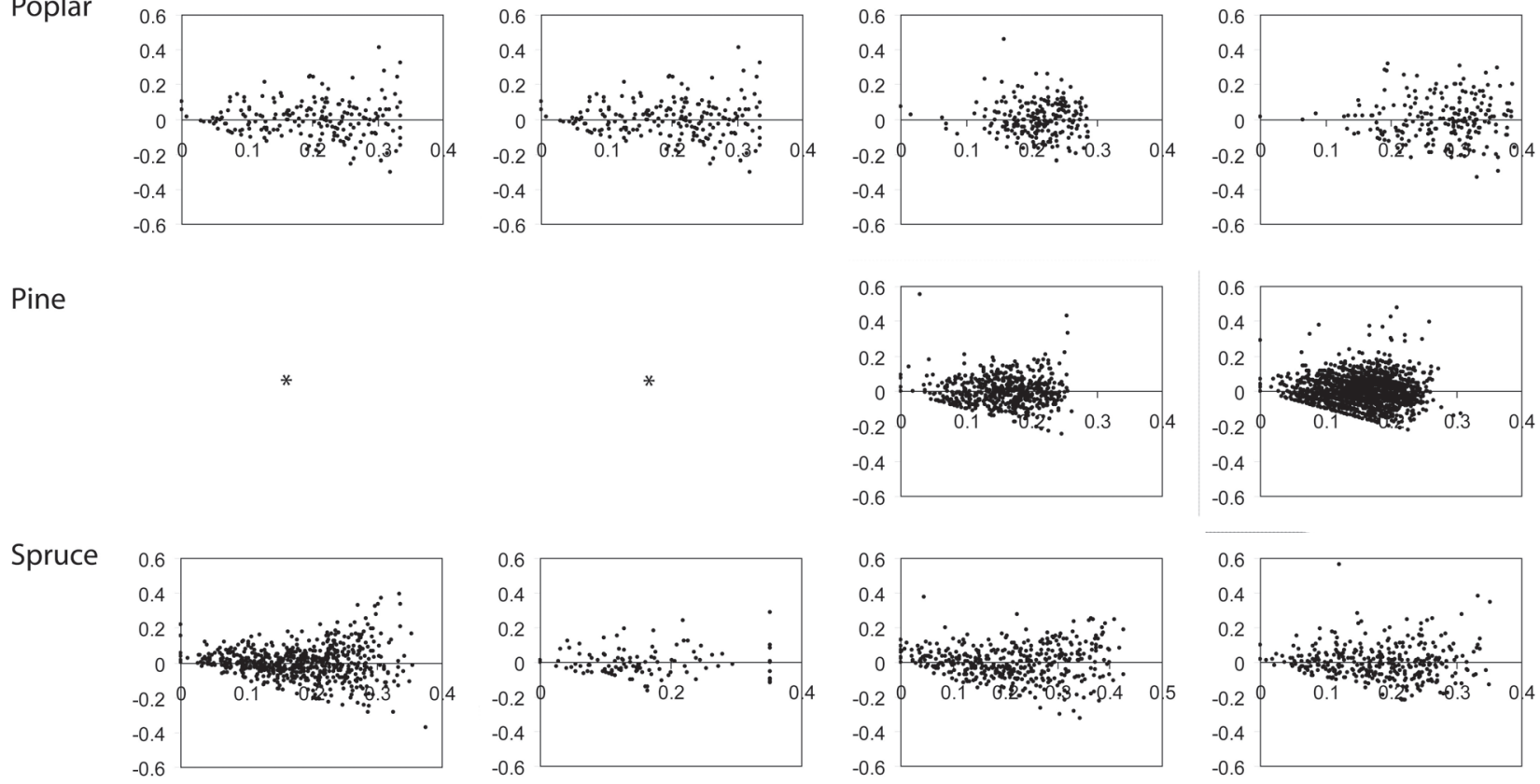

Predicted DBH increment $(\mathrm{cm} / \mathrm{y})$

Figure 4. Residual plots for annual $d b h$ growth (observed - predicted vs. predicted) for the crowding model (Eq. (5)) by ecosite and subject tree species. Missing plots (*) are due to insufficient numbers of some species in some ecosites.

five tree species were clearly different in the effects of their basal area on subject trees, as shown by the tests for grouping the species, and in the different sizes of the regression coefficients corresponding to each competitor species' basal area (below). Combining the species into hardwood-softwood or shade tolerant-intolerant groups resulted in better models than ignoring the species differences, but not as good as models that differentiated the effects of all species.

Ecosite differences were clearly noted, both in the overall test for stratifying the regression models by ecosite (Tab. VI) and in the changes in the competitor species' coefficients across ecosites (Tab. IV). As the species have different niche characteristics, it is rational that competitive relations will change in different climatic and site conditions.

With the exception of lodgepole pine, the rank of the species' competitive effects shown by the size of each competitor species' basal area coefficient (birch $\approx$ spruce $>$ aspen $>$ pine $>$ poplar; Fig. 2) corresponds with these species' crown-level light transmittance [46]. This is not necessarily evidence for the predominance of light competition since the demand for water, nutrients, and light are all positive functions of tree leaf area, but it does show that this empirical ranking is 
mechanistically defensible. Lodgepole pine may be less strong a competitor than its crown light intercepting ability suggests due to the greater amount of intercepting branch and twig area carried by conifers compared to broadleaf trees of similar leaf area [45]. With less green leaf area for the same amount of light interception, their water and nutrient demand will be less than their crown transmittance might suggest.

Interestingly, poorer fits for all competition indices were obtained for the shade intolerant species (aspen, poplar, lodgepole pine) than the shade tolerant (birch, white spruce) (Fig. 1). This may relate to the fact that surviving intolerant species tended to occupy dominant positions in the canopy and experienced a smaller range of competitive intensity. As a large portion of the tolerant spruce and birch subject trees were sub-canopy trees, the range of competition these trees experienced was greater.

A considerable number of species demonstrated amensalism or neutralism rather than competition, and balsam poplar basal area was associated with increased aspen growth in the LFf ecosites (Tab. IV and Fig. 2). Facilitation interactions have been demonstrated by Simard et al. [42] through mycorhizal connections between white birch and Douglas-fir, and may exist for these species as well [28]. However, since this work is based on survey data rather than a controlled experiment, the results reflect complex ecosystem interactions as well as sampling limitations, such as lower numbers of birch and poplar in some ecosites. Since poplar is associated with wetter sites, it is possible that the increase in aspen growth in the presence of poplar reflects a response to site moisture rather than true facilitation. However, other work has shown that commensalism, neutralism and amensalism are common in boreal mixed forests. Aspen provides frost protection for understory trees [35] and suppresses grasses, herbs or shrubs that create more serious growth problems for conifers [31]. The leaf litter of the deciduous species may stimulate nutrient cycling, which may benefit conifer growth [25]. MacPherson et al. [34] found some reduction in aspen productivity in mixed stands of aspen and spruce, but aspen losses were exceeded by the productivity of the spruce, giving mixed stands higher total production than monocultures. The rather poor fits of even the best initial size - competition model tested here $\left(0.16 \leqslant R^{2} \leqslant 0.55\right)$ relative to the model without an explicit competition term $\left(0.11 \leqslant R^{2} \leqslant 0.26\right.$ ) (Fig. 1 ) suggests that inter-tree competition may not be a major process affecting growth of mature western boreal mixed forests.

\section{CONCLUSIONS}

In this examination of competition indices for predicting diameter growth in mixed-species forests, we found that the flexible, distance-dependent crowding index was superior to other indices, but that a simple index, such as competitor basal area was also quite effective. Basal area provided similar fits to many other distance-dependent and independent indices using size ratios or more derived values such as overtopping crown cover. Stratification by competitor species and ecosite improved model performance significantly. More process- oriented indices of light ranked intermediate to poor, possibly due to the lack of precise crown dimension data or competition for other resources. We anticipate a role for distancedependent and light resource indices in modeling the response of mixed-species boreal stands to more extreme spatial heterogeneity created by strip shelterwood harvests [30]; however, for natural-origin unmanaged forests, the costs of collecting the spatial and crown-level information required for distance-dependent and light indices may outweigh their benefit.

Acknowledgements: We thank the Network of Centres of Excellence in Sustainable Forest Management for funding this project, and the Alberta Ministry of Sustainable Resource Development, Land and Forest Division for providing access to their Permanent Sample Plot data. Dr. Christian Messier and Dr. Stephen Titus provided helpful input on this project.

\section{REFERENCES}

[1] Alberta Land and Forest Services, Land and Forest Services Permanent Sample Plot Field Procedures Manual, For. Manage. Div., Edmonton, Alberta, 2002.

[2] Alemdag I.S., Evaluation of some competition indices for the prediction of diameter increment in planted white spruce, Can. For. Serv. Inf. Rep. FMR-X-108, 1978.

[3] Bartelink H.H., Effects of stand composition and thinning in mixedspecies forests: a modeling approach applied to Douglas-fir and beech, Tree Physiol. 20 (2000) 399-406.

[4] Beckingham J.D., Archibald J.H., Field guide to ecosites of northern Alberta, University of British Columbia Press, Vancouver, BC, 1996.

[5] Beckingham J.D., Corns I.G.W., Archibald J.H., Field guide to ecosites of west-central Alberta. University of British Columbia Press, Vancouver, BC, 1996.

[6] Biging G.S., Dobbertin M., A comparison of distance-dependent competition measures for height and basal area growth of individual conifer trees, For. Sci. 38 (1992) 695-720.

[7] Biging, G.S., Dobbertin M., Evaluation of competition indices in individual tree growth models, For. Sci. 41 (1995) 360-377.

[8] Brunner A., A light model for spatially explicit forest stand models, For. Ecol. Manage. 107 (1998) 19-46.

[9] Burton P.J., Some limitations inherent to static indices of plant competition, Can. J. For. Res. 23 (1993) 2141-2151.

[10] Canham C.D., Finzi A.C., Pacala S.W., Burbank D.H., Causes and consequences of resource heterogeneity in forests: interspecific variation in light transmission by canopy trees, Can. J. For. Res. 24 (1994) 337-349.

[11] Canham C.D., Coates K.D., Bartemucci P., Quaglia S., Measurement and modeling of spatially explicit variation in light transmission through interior cedar-hemlock forests of British Columbia, Can. J. For. Res. 29 (1999) 1775-1783.

[12] Canham C.D., LePage P.T., Coates K.D., A neighborhood analysis of canopy tree competition: effects of shading versus crowding, Can. J. For. Res. 34 (2004) 778-787.

[13] Coates K.D., Canham C.D., Beaudet M., Sachs D.L., Messier C., Use of a spatially explicit individual-tree model (SORTIE/BC) to explore the implications of patchiness in structurally complex forests, For. Ecol. Manage. 186 (2003) 297-310.

[14] Comeau P.G., Braumandl T.F., Xie C.Y., Effects of overtopping vegetation on light availability and growth of Engelmann spruce (Picea engelmannii) seedlings, Can. J. For. Res. 23 (1993) 2044-2048. 
[15] Connell J.H., Apparent versus "real" competition in plants, in: Grace J.B., Tilman D. (Eds.), Perspectives on Plant Competition, Academic Press, San Diego, CA, 1990, pp. 9-26.

[16] Corona P., Ferrara A., Individual competition indices for conifer plantations, Agric. Ecosyst. Environ. 27 (1989) 429-437.

[17] Cumming S.G., Schmiegelow F.K.A., Burton P.J., Gap dynamics in boreal aspen stands: is the forest older than we think? Ecol. Appl. 10 (2000) 744-759.

[18] Dang Q.L., Lieffers V.J., Assessment of patterns of response of tree ring growth of black spruce following peatland drainage, Can. J. For. Res. 19 (1989) 924-929.

[19] Daniels R.F., Simple competition indices and their correlation with annual loblolly pine tree growth, For. Sci. 22 (1976) 454-460.

[20] Daniels R.F., Burkhart H.E., Clason T.R., A comparison of competition measures for predicting growth of loblolly pine trees, Can. J. For. Res. 16 (1986) 1230-1237.

[21] Hegyi F., A simulation model for managing jack pine stands, in: Fries J. (Ed.), Growth models for tree and stand simulation, Royal Coll. For., Stockholm, 1974, pp. 74-90.

[22] Holmes M.J., Reed D.D., Competition indices for mixed species northern hardwoods, For. Sci. 37 (1991) 1338-1349.

[23] Huang S., Titus S.J., Lakusta T.W., Held, R.J., Ecologically-based individual tree height-diameter models for major Alberta tree species, Alberta Environ. Prot., Land For. Serv., For. Manage. Div., 1994.

[24] Jones J.R., Review and comparison of site evaluation methods, USDA For. Serv. Res. Pap. RM-51, 1969.

[25] Kelty M., Cameron I.R., Plot designs for the analysis of species interactions in mixed stands, Commonw. For. Rev. 74 (1995) 322 332.

[26] Kucharik C.J., Norman J.M., Gower S.T., Characterization of radiation regimes in nonrandom forest canopies: theory, measurements, and a simplified modeling approach, Tree Physiol. 19 (1999) 695706 .

[27] Larocque G.R., Examining different concepts for the development of a distance-dependent competition model for red pine diameter growth using long-term stand data differing in initial stand density, For. Sci. 48 (2002) 24-34.

[28] Lazaruk L.W., Kernaghan G., Macdonald S.E., Khasa D., Effects of partial cutting on the ectomycorrhizae of Picea glauca forests in northwestern Alberta, Can. J. For. Res. 35 (2005) 1442-1454.

[29] Lieffers V.J., Beck. J.A., A seminatural approach to mixedwood management in the prairie provinces, For. Chron. 70 (1994) 260 264.

[30] Lieffers V.J., Macmillan R.B., MacPherson D., Branter K., Stewart J.D., Semi-natural and intensive silvicultural systems for the boreal mixedwood forest, For. Chron. 72 (1996) 286-292.

[31] Lieffers V.J., Stadt K.J., Growth of understory Picea glauca, Calamagrostis canadensis, and Epilobium angustifolium in relation to overstory light transmission, Can. J. For. Res. 24 (1994) 1193 1198.

[32] Lin J.Y., Stand growth simulation models for Douglas-fir and western hemlock in the northwestern United States, in: Fries J. (Ed.), Growth Models for Tree and Stand Simulation, Royal Coll. For., Stockholm, 1974, pp. 102-118.

[33] Lorimer C.G., Tests of age-independent competition indices for individual trees in natural hardwood stands, For. Ecol. Manage. 6 (1983) 343-360.
[34] MacPherson D.M., Lieffers V.J., Blenis P.V., Productivity of aspen stands with and without a spruce understory in Alberta's boreal mixedwood forests, For. Chron. 77 (2001) 351-356.

[35] Man R.Z., Lieffers V.J., Effects of shelterwood and site preparation on microclimate and establishment of white spruce seedlings in a boreal mixedwood forest, For Chron. 75 (1999) 837-844.

[36] Martin G.L., Ek A.R., A comparison of competition measures and growth models for predicting plantation red pine diameter and height growth, For. Sci. 30 (1984) 731-743.

[37] Navratil S., MacIsaac D.A., Juvenile growth of white spruce and deciduous competition on mixedwood sites in Alberta, Can. For. Serv., PAF Rep. 141, 1996.

[38] Peters V.S., MacDonald S.E., Dale M.R.T., The interaction between masting and fire is key to white spruce regeneration, Ecology 86 (2005) 1744-1750.

[39] Rawlings J.O., Pantula S.G., Dickey D.A., Applied regression analysis: a research tool, 2nd ed., Springer-Verlag, New York, 1998.

[40] Robinson A. P., Ek A.R., The consequences of hierarchy for modeling in forest ecosystems, Can. J. For. Res. 30 (2000) 1837-1846.

[41] Rowe J.S., Forest Regions of Canada, Can. Forestry Serv. Pub. No. 1300, Information Canada, Ottawa, 1972.

[42] Simard S.W., Perry D.A., Jones M.D., Myrold D.D., Durall D.M., and Molina R., Net transfer of carbon between trees species with shared ectomycorrhizal fungi, Nature 388 (1997) 579-582.

[43] Smolander S., Stenberg P., A method for estimating light interception by a conifer shoot, Tree Physiol. 21 (2001) 797-803.

[44] Soares P., Tomé M., Distance-dependent competition measures for eucalyptus plantations in Portugal, Ann. For. Sci. 56 (1999) 307319.

[45] Stadt, K.J., Modeling light for regeneration planning in mixedspecies boreal forests, Ph.D. thesis, University of Alberta, Edmonton, Alberta, 2002.

[46] Stadt K.J., Lieffers V.J., MIXLIGHT: A flexible light transmission model for mixed-species forest stands, Agric. For. Meteorol. 102 (2000) 235-252.

[47] Stadt K.J., Lieffers V.J., Hall R.J., Messier C., Spatially explicit modeling of PAR transmission and growth of Picea glauca and Abies balsamea in the boreal forests of Alberta and Quebec, Can. J. For. Res. 35 (2005) 1-12.

[48] Ter-Mikaelian M.T., Wagner R.G., Bell F.W., Shropshire C., Comparison of photosynthetically active radiation and cover estimation for measuring the effects of interspecific competition on jack pine seedlings, Can. J. For. Res. 29 (1999) 883-889.

[49] Tomé M., Burkhart H.E., Distance-dependent competition measures for predicting growth of individual trees, For. Sci. 35 (1989) 816831.

[50] Vettenranta J., Distance-dependent models for predicting the development of mixed coniferous forests in Finland, Silva Fenn. 33 (1999): 51-72.

[51] Wimberly M., Bare B.B., Distance-dependent and distanceindependent models of Douglas-fir and western hemlock basal area growth following silvicultural treatment, For. Ecol. Manage. 89 (1996) 1-11. 